\title{
Speaker's intentions: the problem of classification
}

\section{N. Dolishnia}

Kyiv National Linguistic University, Kyiv, Ukraine

Corresponding author. E-mail: tatka_oe@ukr.net

Paper received 25.08.18; Accepted for publication 01.08.18.

https://doi.org/10.31174/SEND-Ph2018-177VI52-02

\begin{abstract}
The paper deals with the problem of classification of speaker's intentions. Thorough review of the existing classifications of speaker's intentions enables the author to establish main criteria for classifying intentions. The speaker's intentions are systematised according to the correlation with the pragmatic types of utterances; cognitive, communicative, and sociocultural nature; categorial status; form of realisation in speech; mode of their fulfilment; participant criterion; their direction. Based on the research, an attempt is made to determine the types of intentions that form the speaker's general intention.
\end{abstract}

Keywords: classification/typology/types of speaker's intentions, communicative intention, representative intention, cognitive intention, informative intention, evident and hidden intentions, general intention.

Introduction. The natural development of scientific paradigms contributed to the fact that today a person as a linguistic identity has become the focus of philological researches. In modern linguistics, many efforts are devoted to the investigation of human communication within the scope of communicative and cognitive paradigms. In this vein, the nature of speech production and perception belongs to the most widespread problems of increasing interest. Among them, it is necessary to mention the phenomenon of the speaker's intention in modern dialogical discourse. The majority of scientists agree that one of the most complicated issues in the study of the speaker's intention is the problem of elaboration of its broad and all-purpose classification. Accordingly, the aim of this paper is to give a detailed overview of some already existing classifications of the speaker's intentions as well as to decide what basic types of intentions constitute the speaker's general intention.

Methods of research are determined by the aim of this article. General scientific methods such as analysis, synthesis, induction, deduction, and generalization are employed to provide a systematic review of the literature and to determine the types of intentions that compose the speaker's general intention. Table 1 is used for better illustration of the notion discussed.

Review of publications on the subject. Among various types and kinds of the speaker's intentions, most research is and has been dedicated to the notion of the speaker's communicative intention. The nature of this phenomenon, its typology, and means of realisation in speech are the object of studies of many native and foreign linguists, philosophers, psychologists, experts in other fields. Thus, Professor G. Pocheptsov, the founder of pragmalinguistics in Ukraine, defines the communicative intention as an intrinsic property of the sentence to be directed at solving a certain language task in communication [17, p. 433]. The scholar emphasises that the intention, or, in other words, the communicative and intentional content of the sentence, makes it possible to distinguish six pragmatic types of sentences: constatives, promisives, menasives, performatives, directives, and quesitives [ibid., p. 433-444].

In her monograph dedicated to the study of the category of communicative intention in the Ukrainian language, S. Shabat-Savka also classifies intentions bringing them into correlation with the pragmatic types of utterances.
Therefore, the researcher characterises informative, interrogative, incentive, optative, emotional and evaluative, and interactive intentions as the most relevant ones for the representation of the multifaceted speech activity of the linguistic identity [18, p. 453]. The basis of the informative intention is the need to exchange information and to foresee its possible perception by the interlocutor. The interrogative intention is responsible for the speaker's cognitive processes and the need to fill in information gaps. While the incentive intention induces the hearer to participate in the change of the surrounding world and to react both verbally and non-verbally, the optative intention explains the speaker's wishes, hopes, and desires. Then, the unit of emotional and evaluative intentions represents the speaker's reaction to the pragmatic speech situation, or expresses the speaker's evaluation of somebody or something. The last type of intention is the interactive one that helps to establish and maintain contact between interlocutors, to attract attention of the hearer [18, p. 454-456]. Russian linguist Yu. Antonova introduces a similar classification of communicative intentions [12, p. 78-80]. However, in her thesis, the optative intention is not considered, and the interrogative intention is combined with the incentive one as the part of it.

According to S. Shabat-Savka, the speaker's communicative intention may also be considered from the sociocultural perspective. In this typology, the author divides intentions into four types with respect to the role and status of interlocutors in the society; their gender characteristics; their age characteristics; the stereotypes of the speaker's behavioural needs and linguistic culture of certain ethnic groups [19, p.97]. Finally, the scientist builds a universal typology of the communicative intention that is logical and relevant to the Ukrainian discourse. The category of intention, as S. Shabat-Savka defines it to be, is represented by five types of intentions. The first type incorporates cognitive and mental intentions that are connected with cognitive structures, mental representation of the world, the person's intellectual ability, the emotional and evaluative spheres of the linguistic identity [ibid., p. 360]. The second type includes communicative and modal intentions that describe the speaker's intentional needs via the speaker's communicative needs. These are the informative/declarative, interrogative, incentive, and optative intentions [ibid., p. 361]. The third type of subjective and modal intentions embraces author- 
ized intentions (they introduce the speaker's subjective viewpoint), intentions of credibility (they indicate the degree of the speaker's awareness of certain facts and events), intentions of hypothesis expression (they convey the meaning of probability, doubt, assumption, uncertainty) [ibid., p. 361-364]. The next type of intentions consists of discourse intentions and those related to genre differentiation of speech. They all form the paradigm of aesthetic intentions in fiction, conversational intentions in dialogical discourse, intentions of influence in publicistic discourse, I-intentions in epistolary discourse, sacral intentions in religious discourse, argumentative intentions in academic discourse, and regulation intentions in formal discourse [ibid., p. 364-365]. Intentions of social regulation and interactive intentions constitute the metacommunicative type of intentions [ibid., p. 366].

P. Jacob studied the notion of intentionality from the philosophical perspective and presented a comprehensive review of his research on intentions in the article "Meaning, Intentionality and Communication." This French philosopher starts his discussion with how F. Brentano understood intentionality within the framework of phenomenology and how the concept is defined by J.L. Austin, H.P. Grice, other modern philosophers and pragmatists [4, p. 12]. Incidentally, it was H.P. Grice who suggested making a distinction between two types of meaning: the linguistic meaning and the speaker's meaning $[1 ; 2 ; 4 ; 6]$. In other words, it is necessary to distinguish between what is said in the utterance and what is meant by this utterance. Referring to the Gricean theory of speaker's meaning, P. Jacob says that the content of the utterance may be explicit and implicit. Therefore, it is possible to speak about the existence of explicit and implicit communicative intentions that predetermine the content of the utterance $[4$, p. 11]. The fact that the typology of intentions should also consider the criterion of explicitness and implicitness may be proved by the words of T. Pratchett, a renowned British fantasy writer. In the book Reaper Man, he declares, "There was never anything to be gained from observing what humans said to one another - language was just there to hide their thoughts" [5, p. 290].

$\mathrm{Yu}$. Antonova is another researcher who has tried to systematise communicative intentions in accordance with the form of realisation of intentions in speech. She distinguishes between evident and hidden intentions, the recognition of the latter depends on the interlocutors' background knowledge, their understanding of conventional and conversational implicatures [12, p. 81-94]. The same approach to evident and hidden intentions is adopted by N. Mukhina, although, in her thesis, the linguist regards intentions as goals [16].

H.P. Grice, who became famous for his fundamental works about the nature of communication and the theory of meaning, also contributed much to the investigation of the communicative intention [1, p. 359]. He defined communication as the intentional influence on the hearer's psychological state. The key element in the fulfilment of the communicative intention is making the target audience recognise the speaker's intention to influence somehow this audience $[1$, p. $359 ; 2$, p. 92; 8, p. 47]. This approach is adopted by such scholars as J.R. Searle, K. Bach, and F. Recanati in their research works $[1 ; 6 ; 8]$.
H.P. Grice concludes that a communicative intention is self-referential, or reflexive, because the speaker has an intention to communicate some information and a further intention that the target audience will recognise this first intention $[1 ; 2 ; 6]$. However, it does not imply that then the aforementioned recognising process caused by further intentions endlessly continues. Hence, the question of reflexive communicative intentions is the subject of much debate [1, p. 359]. In addition, in H.P. Grice's account, the communicative intention is global and consists of several sub-intentions the one of which is the hearer's recognition of the speaker's communicative intention [6, p. 240].

With reference to J.R. Searle, an American philosopher and currently the Emeritus Professor at the University of California, the notion of intention may be classified according to the participant criterion. It is subdivided into the individual intention of the addresser, the individual intention of the addressee, and the collective intention that enables the participants to act in a coordinated and cooperative fashion, and to achieve collective goals [7; 13]. Moreover, Searle emphasises that collective intentionality is a phenomenon which cannot be analysed as "the summation of individual intentional behavior" [7, p. 403]. As a result, the notion of the collective intention should be investigated as an independent type of intention in this taxonomy.

Discussion. It is clear that the communicative intention and its typology are the focus of scrupulous scientists' attention. However, fewer research papers are devoted to other types of intentions. Nevertheless, to investigate such a complex phenomenon as the speaker's intention, it is not enough to scrutinise only its communicative aspect. One reason is that this research would be at least onesided and incomplete, if not ambiguous. Therefore, a variant of the speaker's intentions typology was introduced by D. Wilson, a British linguist and cognitive psychologist, and D. Sperber, a French social and cognitive scientist. In their article "Relevance Theory," these researchers argue that two levels of intentions are involved in ostensive communication: the informative intention and the communicative one. D. Sperber and D. Wilson explain, "The speaker's informative intention is to inform the audience of something. The communicative intention is to inform the audience of one's informative intention. Understanding is achieved when the communicative intention is fulfilled - that is, when the audience recognizes the informative intention" [10, p. 611]. This attitude to the classification of intentions is close to the one of H.P. Grice's and his followers, but it characterises the informative intention as a separate type.

Other scientists suppose the intention to be a complex phenomenon that incorporates both a cognitive and a communicative aspect in its nature $[13$, p. $13 ; 14]$ because the notion discussed is not only a linguistic term, but also a subject of numerous studies in psychology and philosophy. In fact, the term "intention" originated in philosophy where intentionality is usually expounded as an essential property of mental states to be directed at or oriented towards something [3; 9, p. 48]. Ukrainian researcher L. Bezugla insists that it is crucial to distinguish between the communicative intention and the representative one. The representative intention means that the speaker's 
mind is directed at a particular object or state of affairs in the world [9, p. 48], while the communicative intention is the speaker's purpose to communicate the representative intention to the hearer and to make the hearer react [13, p. 13]. This distinction between communicative and representative intentions corresponds to the distinction between the main functions of the language: communicative and cognitive [13; 19]. Similarly, Russian philologist N. Klushina differentiates between the communicative intention and the cognitive intention. In her opinion, the latter forms the cognitive world of a person; that is why, it is more appropriate to call it the cognitive intention. The communicative intention is directed at achieving the speaker's aims [14]. It is necessary to mention that L. Bezugla considers a representative (or cognitive, with reference to $\mathrm{N}$. Klushina) intention and a communicative intention to be two different types of the intention [13, p. 13], while N. Klushina argues that these are the components of the author's general intention [14]. Consequently, it is not possible to consider them separately. A fortiori, E. Kubryakova explains that modern science is the synthesis of cognition and communication [15, p. 16].

Apart from the peculiarities reported above, it is worthwhile to closely examine other similarities and differences between the representative/cognitive and the communicative aspects of intention. As it was stated, these two types (or components) of the speaker's intention are characterised by their direction focused on something. Secondly, just as the representative/cognitive intention has the aim of its direction at objects and states, so too the communicative intention has its aim of the direction. The representative/cognitive type (or component) of intention, directed at the outside world, creates the inner world of the person. To cognise and recognise the phenomena of life and the person's own self is the primary aim of this type of intention, whereas the communicative intention is realised to somehow produce an effect on the target audience and to reach the speaker's own goals [9, p. 48; 14]. Thirdly, both of the intentions in question have some inherent characteristic features in their nature. Being obligatory, the representative/cognitive intention contrasts with the communicative intention, which is optional, because communication is not always realised in its verbal form [14]. Finally, the representative/cognitive type of the speaker's intention correlates with the cognitive function of the language $[13 ; 19]$ and, consequently, is studied by cognitive pragmalinguistics. On the other hand, the communicative type of the speaker's intention corresponds to the communicative function of the language [ibid.] and, therefore, is a subject of research in communicative pragmalinguistics. These common and distinctive features that pertain to the representative/cognitive and communicative aspects of the speaker's intention may be summarised in the form of a table (Table 1).

Table 1. The comparison of the representative/cognitive intention and the communicative intention

\begin{tabular}{|c|c|c|}
\hline \begin{tabular}{|l|l} 
Criteria & Intentions \\
\end{tabular} & $\begin{array}{c}\text { Representative / Cognitive } \\
\text { intentions }\end{array}$ & Communicative intentions \\
\hline Direction & $\begin{array}{l}\text { Directed at or about objects and } \\
\text { states of affairs in the world }\end{array}$ & $\begin{array}{l}\text { Directed at or about achieving } \\
\text { speaker's communicative aims }\end{array}$ \\
\hline $\begin{array}{l}\text { Correlation with the main } \\
\text { functions of the language }\end{array}$ & Cognitive function & Communicative function \\
\hline Aim & $\begin{array}{l}\text { To cognise the phenomena of life } \\
\text { and the person's own self }\end{array}$ & $\begin{array}{l}\text { To achieve communicative } \\
\text { aims, to influence the audience }\end{array}$ \\
\hline Inherent characteristic feature & Obligatory & Optional \\
\hline $\begin{array}{l}\text { The branch of pragmalinguis- } \\
\text { tics }\end{array}$ & Cognitive pragmalinguistics & $\begin{array}{l}\text { Communicative pragmalin- } \\
\text { guistics }\end{array}$ \\
\hline
\end{tabular}

In her thesis about the intention of promise, Russian philologist A. Antonova suggests her model of the general intention that includes the informative and the communicative intentions as well as a number of subsidiary intentions (they help to produce a correct utterance from the point of view of phonetics, grammar, semantics, and genre) $[11$, p. 37]. Following this and the previously mentioned studies, it is possible to construct a working model of the speaker's general intention through an integrated approach to the notion. The model incorporates the communicative, cognitive, and subsidiary intentions as the basic types of the general intention. Evident and hidden intentions require careful consideration in this piece of research.

Conclusions. Taking everything mentioned above into account, the classifications of the speaker's intentions are based on multiple parameters which leads to inconsistency. In addition, such classifications do not cover all sides of the complex notion that embraces both a cognitive and a communicative aspect in its nature. Consequently, it is essential to perform a careful analysis of the existent classifications of the speaker's intentions as well as to attempt to discover what basic types of intentions represent the speaker's general intention. Moreover, since the intention of the speaker is the subject of research in phenomenology, psychology, cognitive and communicative pragmalinguistics, researchers often have different, even opposing, views on the issue. Therefore, it is also necessary to pay particular attention to the difference in comprehension of the notion under investigation in various branches of science. Further revision of the model and types of the speaker's general intention will increase understanding of the phenomenon of intention and may help to develop some universal principles of the effective communication theory.

\section{ЛІТЕРАТУРА}

1. Bach, K. Grice, H. Paul // The MIT Encyclopedia of the Cognitive Sciences / edited by R.A. Wilson and F.C. Keil. Cambridge, MA: The MIT Press, 1999. P. 359-360.

2. Grice, H.P. Studies in the Way of Words. Harvard: Harvard University Press, 1991. 406 p.

3. Jacob, P. Intentionality // The Stanford Encyclopedia of Philosophy (Winter 2014 Edition) / edited by E.N. Zalta. Stan- 
ford, CA: Metaphysics Research Lab, Stanford University, 2014.

URL: https://plato.stanford.edu/archives/win2014/entries/intentiona lity/ (accessed: 15.06.2018).

4. Jacob, P. Meaning, Intentionality and Communication // Semantics: An International Handbook of Natural Language Meaning / edited by C. Maienborn, K. von Heusinger, and P. Portner. De Gruyter Mouton, 2011. № 2. P. 11-25. URL: https://jeannicod.ccsd.cnrs.fr/ijn_00755975

(accessed: 16.12.2016)

5. Pratchett, T. Reaper Man. London: Transworld Publishers Ltd, 2012. $352 \mathrm{p}$

6. Recanati, F. On Defining Communicative Intentions // Mind and Language, 1986. № 1(3). P. 213-242.

7. Searle, J.R. Collective Intentions and Actions // Intentions in Communication / edited by Ph.R. Cohen, J. Morgan, and M.E. Pollack. Cambridge, MA: The MIT Press, 1990. P. 401415. guage. Cambridge: Cambridge University Press, 1969. 214 p.

9. Searle, J.R. The Intentionality of Intention and Action // Cognitive Science, 1980. № 4(1). P. 47-70. book of Pragmatics / edited by L.R. Horn and G. Ward. Oxford: Blackwell, 2004. P. 607-632.

11. Антонова А.В. Интенция обещания и средства ее выражения в английском языке: дис. ... канд. филол. наук: спец. 10.02.04 «Германские языки». Самара, 2004. 190 с.
8. Searle, J.R. Speech Acts. An Essay in the Philosophy of Lan-

10. Wilson, D., and D. Sperber. Relevance Theory // The Hand-

12. Антонова Ю.Н. Интенция говорящего в аспекте коммуникативно-целевой семантики: дис. ... канд. филол. наук: спец. 10.02.19 «Теория языка». Орел, 2006. 183 с.

13. Безугла Л.Р. Когнітивно-прагматичні характеристики імпліцитних смислів у німецькомовному дискурсі: автореф. дис. ... доктора філол. наук: спец. 10.02 .04 «Германські мови». Київ, 2009. 28 с.

14. Клушина Н.И. Интенциональный метод в современной лингвистической парадигме // Электронный научный журнал «Медиаскоп», 2012. № $4 . \quad$ URL: http://mediascope.ru/node/1242 (дата обращения: 23.11.2016).

15. Кубрякова Е.С. Об установках когнитивной науки и актуальных проблемах когнитивной лингвистики // Вопросы когнитивной лингвистики, 2004. № 1(001). С. 6-17.

16. Мухина Н.Б. Цель как коммуникативно-прагматический фактор организации речевой деятельности говорящего (на материале современного английского языка): автореф. дис. ... канд. филол. наук: спец. 10.02.04 «Германские языки». Уфа, 2004. 23 с.

17. Почепцов Г.Г. Избранные труды по лингвистике: монография / сост., общ. ред. и вступ. статья И.С. Шевченко. Харьков: ХНУ имени В.Н. Каразина, 2009. 556 с.

18. Шабат-Савка С.Т. Дискурс як релевантний спосіб втілення комунікативних інтенцій // Studia Linguistica, 2011. № 5. C. 451-457.

19. Шабат-Савка С.Т. Категорія комунікативної інтенції в українській мові. Чернівці: «Букрек», 2014. 412 с.

\section{REFERENCES}

1. Antonova, A.V. Intentsiya obeshchaniya i sredstva yeye vyrazheniya $\mathrm{v}$ angliyskom yazyke [The Intention of Promise and Means of its Realisation in the English Language]: dissertation thesis for the Candidate degree in Philology: Speciality 10.02.04 "Germanic Languages." Samara, 2004. 190 p.

2. Antonova, Yu.N. Intentsiya govoryashchego v aspekte kommunikativno-tselevoy semantiki [The Speaker's Intention in the Aspect of Communicative-Target Semantics]: dissertation thesis for the Candidate degree in Philology: Speciality 10.02.19 "The Theory of Language." Orel, 2006. 183 p.

3. Bezugla, L.R. Cognitive-Pragmatic Characteristics of Implicit Meanings in German Discourse: extended abstract of a thesis for the Doctoral degree in Philology: Speciality 10.02.04 "Germanic Languages." Kyiv, 2009. 28 p.

4. Klushina, N.I. Intentional Method in the Modern Linguistic Paradigm // Mediascope: The Online Scientific Journal, 2012. № 4. URL: http://mediascope.ru/node/1242 (accessed: 23.11.2016).

5. Kubryakova, E.S. Of Cognitive Science Guidelines and Vital Problems of Cognitive Linguistics // Voprosy kognitivnoy lingvistiki, 2004. № 1(001). P. 6-17.
6. Mukhina, N.B. Tsel kak kommunikativno-pragmaticheskiy faktor organizatsii rechevoy deyatelnosti govoryashchego (na materiale sovremennogo angliyskogo yazyka) [The Goal as a Communicative and Pragmatic Factor in the Organization of the Speaker's Speech Activity (A Study of Modern English)]: extended abstract of a thesis for the Candidate degree in Philology: Speciality 10.02.04 "Germanic Languages." Ufa, 2004. 23 p.

7. Pocheptsov, G.G. Izbrannyye trudy po lingvistike [Selected Works on Linguistics]: monograph / edited by I.S. Shevchenko. Kharkiv: Vasyl Karazin Kharkiv National University, 2009. 556 p.

8. Shabat-Savka, S.T. Dyskurs yak relevantnyy sposib vtilennya komunikatyvnykh intentsiy [Discourse as a Relevant Means of Realisation of Communicative Intentions] // Studia Linguistica, 2011. № 5. P. 451-457.

9. Shabat-Savka, S.T. Katehoriya komunikatyvnoyi intentsiyi v ukrayinskiy movi [The Category of Communicative Intention in the Ukrainian Language]. Chernivtsi: "Bukrek," 2014. $412 \mathrm{p}$. 